\title{
Components of business concepts for the diffusion of large scaled environmental technology systems
}

Wisdom Kanda, Sakao Tomohiko and Olof Hjelm

\section{Linköping University Post Print}

\section{Tweet}

N.B.: When citing this work, cite the original article.

Original Publication:

Wisdom Kanda, Sakao Tomohiko and Olof Hjelm, Components of business concepts for the diffusion of large scaled environmental technology systems, 2015, Journal of Cleaner Production.

http://dx.doi.org/10.1016/j.jclepro.2015.10.040

Copyright: Elsevier

http://www.elsevier.com/

Postprint available at: Linköping University Electronic Press

http://urn.kb.se/resolve?urn=urn:nbn:se:liu:diva-122235 


\title{
Components of business concepts for the diffusion of large scaled environmental technology systems
}

\author{
Wisdom Kanda*, Tomohiko Sakao, Olof Hjelm \\ Environmental Technology and Management, Department of Management and Engineering, \\ Linköping University, SE-581 83 Linköping, Sweden. \\ *Corresponding author: E-mail address: wisdom.kanda@liu.se Tel.: +46 (0)13281696
}

\begin{abstract}
Strategies for sustainable development are arguably part of the most discussed issues among political and corporate actors. These discussions are spurred by global challenges such as climate change, urbanization, and critical natural resource depletion. Sustainable development will require deep structural and wide-reaching changes in current institutions, technologies, and businesses. Furthermore, new approaches are needed to facilitate the development, diffusion, and implementation of environmental technologies. In the academic discourse different concepts, e.g., ecodesign and Product/Service System design, have been proposed within the framework of sustainable development. To deliver even more system-wide environmental improvements, these concepts have been challenged to be expanded in focus beyond products and services to include large technical systems encompassing nontechnological dimensions. Motivated by these, the goal of this article is twofold. First, to offer an expanded view on ecodesign of product/service systems using a perspective of large technical systems. Second, to propose and discuss important components to consider when developing business concepts for the diffusion of large scaled environmental technology systems such as district heating supply, waste management, and renewable energy systems. Using qualitative semi-structured interviews and company documentation analysis, this study examines five companies that develop and diffuse large scaled environmental technology systems. As a result of these case studies, we propose components of business concepts that incorporate both technological and non-technological dimensions. Our proposed business concept components are: market (including regulation), finance, resources, activities, partnership (especially public-private partnership), ownership and responsibility, and legitimacy. Regulation, public-private partnership, and legitimacy are particularly important in the diffusion of large scaled environmental technology systems.
\end{abstract}

Keywords: Large technical systems; Business model; Technology diffusion; Product/Service System; Ecodesign

Word count: (10108 words) 


\section{Highlights}

1. Business concept components for environmental technology diffusion are proposed.

2. Legitimacy, private-public partnership and regulation are important components.

3. The focus of ecodesign is expanded to encompass large technical systems.

4. Potentially higher environmental performance is expected in the expanded focus.

5. Business concepts offer opportunities to realize such environmental benefits. 


\section{Introduction}

In recent years, sustainable development has received renewed global interest as an increasing number of firms are reporting profitability from sustainability investments (Rohrbeck et al., 2013). In addition to corporate interests, there is an upsurge in political interest in sustainable development amidst public awareness and pressure (Boons et al., 2013). This renewed corporate, political, and public interest in sustainable development is spurred by major trends shaping the emerging future such as climate change, rapid population growth and urbanization, increased pollution, and scarcity of critical raw materials. The global nature of these environmentally relevant challenges means that short-term quick-fix solutions are not applicable, so it has become vital that sustainable development encompasses long-term and far-reaching changes in technology, infrastructure, lifestyles, and institutions (Rennings, 2000). Although not sufficient, technological changes are regarded as necessary for sustainable development (del Rio González, 2009), and recent efforts by international organizations such as the OECD to stimulate industry towards sustainability (cf. OECD, 2009) point to the need for continued efforts in the rapid development and diffusion of environmental technologies (Rennings, 2014; Suzuki, 2014).

Since the early 1990s, academic discourse has provided insights into environmentally conscious design (ecodesign), including its concepts, models, methods, tools, and their application (e.g., Alting and Legarth, 1995; Baumann et al., 2002; Karlsson and Luttropp, 2006; Ramani et al., 2010). Ecodesign mainly addresses material selection, packaging, part recyclability, modular structure, and functional optimisation within physical products. In the late 1990s, research about Product/Service System (PSS) (Boehm and Thomas, 2013; Meier et al., 2010; Mont, 2002; Mont and Tukker, 2006; Tukker, 2013) emerged in part to overcome some limitations of ecodesign. PSS design enhances ecodesign by incorporating service (repair, performance guarantee, take-back, etc.) into the design space. PSS typically addresses products such as a copier, an aircraft engine, or a production machine with their related services. However, a gap exists between the long-term and far-reaching changes needed for sustainability and the insights gained from ecodesign and PSS design. This gap is characterised by three limitations. First, little literature exists about ecodesign and PSS design that targets large scaled environmental technology systems such as district heating supply, waste management, and renewable energy systems. Second, most of the literature about ecodesign and PSS deal with business-to-consumer and business-to-business context, but these large-scaled systems are often dealt with in the context of business-to-government as well. Third, these large systems are typically associated with changes in social norms, cultural values and formal institutional structures and conditions that are typically outside the focus of ecodesign and PSS design. However, non-technological changes can potentially deliver system-wide environmental improvement needed for sustainable development compared to improvements that only focus on processes and products (OECD, 2009).

Among different reasons, the lack of proper handling of the business aspects of environmental technology development is deemed as a significant barrier in their diffusion (Cerin et al., 2007). As signals for the development and diffusion of environmental technologies continue to grow strong, it has become evident that improvements are needed in the current efforts and 
approaches to exploit their development, diffusion, and implementation (Kanda et al., 2013). The concept of business models oriented towards sustainability can provide a link between firm efforts and system-level sustainability, and this insight is receiving attention from researchers, policy makers and business managers alike (Boons et al., 2013). Similarly, business models are expected to provide relevant support for firm-level development and diffusion of environmental technologies, particularly within the framework of sustainability. What makes such business models even more compelling is that current short-term profitability-oriented business models and strategies can cause economic, ecological, and ethical problems and stifle the diffusion of environmental technologies including the expected environmental benefits.

The goal of this article is thus twofold: to offer an expanded view on ecodesign of Product Service Systems (PSS) using a perspective of large technical systems, and to propose and discuss important components to consider when developing business concepts for the diffusion of large scaled environmental technology systems. The expansion of the focus of PSS to include insights from large technical systems is motivated by the distinguishing characteristic of environmental technologies, which is to improve environmental performance. Even though environmental performance is influenced by several factors, the design dimension is decisive for several technologies (Carrillo-Hermosilla et al., 2010). Thus, an expansion of PSS design from products and services to large technical systems embodies potentially radical environmental improvements in comparison with environmental improvements from modifications in products and services. Furthermore, to deliver such environmental improvements, these large technical systems need market introduction and diffusion. Ultimately, the capacity of environmental technologies to contribute to sustainability transitions depends on the interplay between the design dimension and factors influencing market introduction, including the engagement of key stakeholders (CarrilloHermosilla et al., 2010). This link between the design dimension and diffusion is what the twofold research questions guiding this study aim to provide.

To achieve these goals, we discuss environmental technology diffusion and the concepts of ecodesign and PSS design in Section 2, ending with a theoretical expansion of PSS design to large technical systems which corresponds to the first goal of the article. In Section 3, we then present the research method used to answer the second goal. Next, in Section 4 our findings from the empirical case studies are presented. In Section 5, we go on to propose and discuss components of business concepts for the diffusion of environmental technology, corresponding to the second goal of the article. Finally, in Section 6 we conclude on the research goals and identify further research opportunities.

\section{Expansion of ecodesign from products and services to large technical systems}

This section starts broadly with the concept of environmental technology, including its definition in the context of this article, before narrowing down to a review of some conceptual frameworks on the diffusion of environmental technologies. We then highlight some particular characteristics of large technical systems which could influence their diffusion. In 
addition, we discuss the concepts of ecodesign and PSS design, ending with a theoretical expansion in the focus on these concepts to encompass large technical systems, which corresponds to the first goal of the article. Furthermore, these discussions also serve as inputs both for the empirical data collection and analysis.

\subsection{Environmental technology diffusion}

The term "environmental technology" (ET) is used synonymously with a variety of terms such as "environmentally sound technology", "cleantech", "green technology", and "low carbon technology". Since the term has no internationally agreed upon definition, different definitions exist in the academic and public domains ( See Guziana, 2011for a broader review on different definitions on the term). For example, Kemp (1997, p.11) defines environmental technology broadly as each "technique, process or product which conserves or restores environmental qualities" (cited in (Guziana, 2011). In the public discourse, the EU (2004, p.2) defines environmental technologies as: "all technologies whose use is less environmentally harmful than relevant alternatives. They encompass technologies and processes to manage pollution (e.g. air pollution control, waste management), less polluting and less resourceintensive products and services and ways to manage resources more efficiently (e.g. water supply, energy-saving technologies)". Despite the academic debates on the definition of the term, the realisation of actual environmental improvements as against the intention for environmental improvement, the radical or incremental nature of such technologies, and whether the term encompasses both technical and non-technical aspects, a defining characteristic of environmental technologies is their environmental improvements. Thus, in this article we refer to "environmental technology" as technologies (products, services, and large technical systems) whose development and use actually provide or are intended to provide better environmental performance from a life cycle perspective compared to their relevant alternatives. Our understanding of the term is purposively broad and includes different types of technologies developed by the studied companies targeted at waste management, renewable energy and district heating supply. In addition, we embrace both the actual realisation of environmental benefits and the intention to do so with technical and nontechnical approaches as part of our understanding of the concept of environmental technology.

On the phenomenon of technology diffusion, Rogers defines diffusion in a broad sense as "the process by which an innovation is communicated through certain channels over time among the members of a social system" (Rogers, 2010). Technology diffusion describes the aggregate adoption decision by a population of potential adopters over time and is influenced by numerous factors, and is thus complex to model in its entirety (Kemp and Volpi, 2008). Departing from the seminal contribution of Rogers, some recent theoretical frameworks on the diffusion of environmental innovations are relevant in the context of this article. For example, Beise and Rennings (2005) introduce the concept of lead markets to analyse countries that first adopt a globally dominant innovation design, and thus enjoy leadership in the international diffusion through export of the innovation and by setting the global standard. They identify five advantages as influential in the creation of such lead markets for "environmental innovations": (i) price advantage, (ii) demand advantage, (iii) transfer advantage, (iv) export advantage and (v) regulation. Moving on from the national to firm 
levels, other contributions (e.g. Hockerts and Wüstenhagen, 2010) focus on supply-side concepts such as the "David and Goliath model". The authors discuss providers of "sustainable innovations" (i.e. start-ups vs. incumbents) including their different roles, specific opportunities and challenges, and interactions between their entrepreneurial initiatives under the context of industrial transformation towards sustainability. The authors propose a dynamic view of industrial transformation where the initial phase is characterised by sustainability initiatives by idealistic start-ups, while the second phase is characterised by the response of incumbents with higher quality position who mimic some of the initiatives of start-ups and try to bring them to the mainstream markets. Based on these previous contributions and an empirical analysis of the diffusion pathways of a hundred "sustainability innovations", Fichter and Clausen (2012) identify seven key factors of particular significance in the diffusion of sustainability innovations. These factors are: (i) the market power of established providers, (ii) political push and pull, (iii) the influence of pioneers, (iv) purchase incentives, (v) compatibility with routines, (vi) price and economic viability and (vii) the transparency of innovation.

For adopters, the decision to adopt an environmental technology is influenced by a variety of technological, social, economic, and institutional factors (Montalvo, 2008). Some of these factors are internal to the firm (e.g., financial commitment, absorptive capacity such as technological competency, and skilful human resources) and the commitment of top management. Other decision factors are external to the firm, such as regulation and pressure from networks and competitors (del Río González, 2005). Particular adoption factors related to the technology itself include its complexity, alignment with existing systems (MejíaDugand et al., 2012), the importance of financing (del Rio González, 2009), and the requirement of collaboration from multiple actors (Rohrbeck et al., 2013). These previous contributions present factors which influence the diffusion of environmental technology from the perspective of the technology provider and potential adopter, also on the national and firm levels.

With regards to the technology characteristics, large technical systems such as district heating supply, waste management, and renewable energy systems - the focus of this article encompass capital-intensive infrastructure with a broad range of technical components and technologies and a variety of associated actors and institutions (Markard and Truffer, 2006). The system components are often closely interrelated and are shaped by various kinds of technical norms, organizational practices, and institutional regulations, all of which coevolved with the technical system and contribute to its stability and inertia to change. Similar large technical systems can be identified with water supply, railway, and telecommunication systems. Although the term large technical systems often suggest a technical system, it also encompasses non-technical aspects such as regulations, norms, user patterns, standards, networks, and investors. The consideration of both technical and non-technical aspects in large technical systems opens up the potential for system-wide environmental improvements compared to environmental improvements focused solely on technical dimensions (OECD, 2009). For example, compared to the use of motorcycles and personal cars, case studies indicate that public buses reduce both local and global greenhouse gas emissions and 
stimulate changes in policy, vehicle engine technology, and user behaviour (Dirgahayani, 2013). Even so, some conceptual examples also indicate both environmental and economic benefits from large integrated district heating systems compared with decentralised heating (Wang et al., 2010). Furthermore, if these large technical systems are designed and developed using extended insights from ecodesign and PSS design, potentially radical system-wide environmental improvements can be obtained acknowledging the decisive role the design dimension contributes to the environmental performance of environmental technologies (Carrillo-Hermosilla et al., 2010).

\subsection{Expansion of ecodesign and Product/Service System design}

Within the contexts of innovation, production and consumption, sustainable development is operationalized using different strategies. Early industrial approaches in the 80s focused on pollution control mainly with "end-of-pipe" technologies. In the mid-90s, approaches focused on pollution prevention and cleaner production with "front-of-pipe" technologies and a philosophy to anticipate and prevent environmental damage (OECD, 2009). Within this proactive approach, strategies such as environmentally conscious product design - ecodesign - emerged.

Ecodesign deals with the integration of multifaceted aspects of design and environmental performance, with the main objective to improve product development with environmental considerations (Karlsson and Luttropp, 2006). Different terms are used to refer to the same notion as ecodesign, e.g. life cycle design (Alting and Legarth, 1995; Ramani et al., 2010), design for environment (Fiksel, 1996), and green product development (Baumann et al., 2002). The integration of environmental considerations has been partly motivated by the significant impact the design phase of a product has on environmental performance during its production, use, and end-of-life treatment (Lindahl, 2005). Although several definitions exist for ecodesign, Karlsson and Luttropp (2006) conclude that ecodesign is about design in and for a sustainable development context. Different methods and techniques for ecodesign (e.g. Baumann et al., 2002; Ramani et al., 2010) have been developed, and some are used in industry today (e.g. Knight and Jenkins, 2009). These methods and techniques support material selection, design for recyclability, modular design, product packaging, and functional optimisation. Although ecodesign is crucial for the environmental performance of products (e.g., personal computers and refrigerators), criticisms exist over the potential increase in total life cycle environmental impact of ecodesigned products. Sakao and Shimomura (2007), for example, point out that ecodesign is the design of a product that by definition excludes control over the subsequent phases of the product's life such as its production, use, and end-of-life treatment.

Partly as a response to the limitations of ecodesign highlighted above, the concept of Product-Service System (PSS) was introduced (Mont and Tukker, 2006). The PSS concept focuses on delivery of functionality by combining products and services to satisfy customer needs with a potentially lower environmental impact than traditional product sales (Mont, 2002). For example, Rolls-Royce offers gas turbine engines and related services under a contract termed "power-by-the-hour" and is paid for performance rather than for selling engines (Smith, 2013). Instead of companies selling more products to maximize revenues, 
PSS approaches incentivise companies to minimize material consumption and increase product reuse, remanufacturing, and recycling. Different methods have been developed for PSS (Meier et al., 2010; Tukker, 2013), and environmental benefits from PSS are claimed in some practical cases (Lindahl et al., 2014). Yet, insights from ecodesign and PSS design gained thus far are not sufficient for the ecodesign of large technical systems, which often deal with business-to-government contexts as well as non-technological dimensions such as social norms, cultural values, and formal institutional structures. In particular, a combination of technological and non-technological changes can potentially deliver system-wide environmental improvement compared to modifications in processes and products (OECD, 2009). This theoretical expansion of environmentally conscious design from products and services to large technical systems in depicted in Figure 1 below.

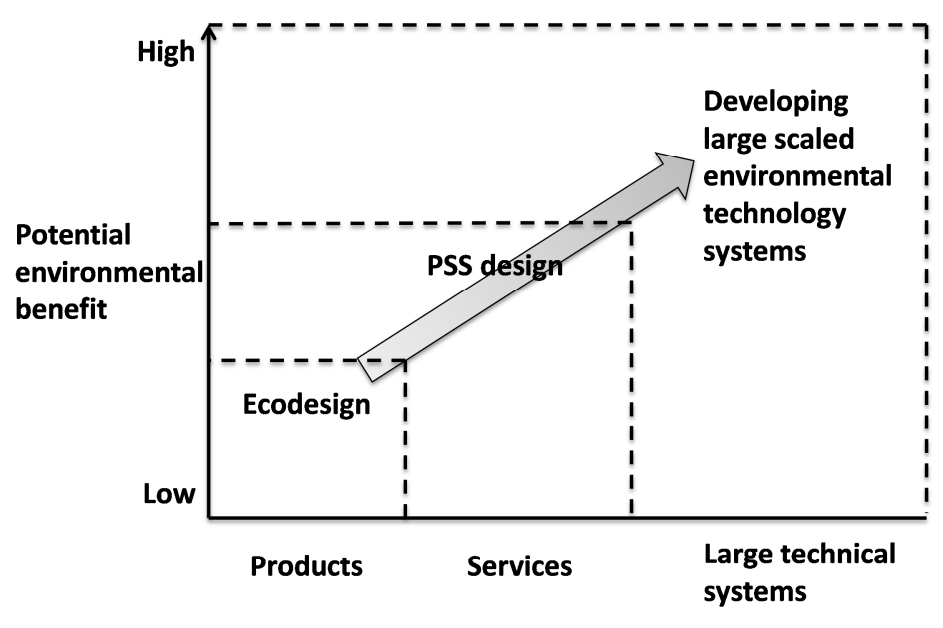

$<<$ Position of Figure 1 $>>$

Figure 1. Expansion of ecodesign from product and service to large technical system.

In Figure 1, the vertical axis depicts potential environmental benefits in this theoretical expansion. The potential environmental benefits delivered from concepts such as ecodesign and PSS design have been gained from improvements in products and services with few insights on large technical systems such as district heating supply, waste management, and renewable energy systems. However, large technical systems that combine technological (e.g. processes and products) and non-technological (e.g., institutions, organisations, human factors, and social factors) dimensions have the potential for much more significant environmental improvement (OECD, 2009), needed for sustainability. This is because they consider several technical components, actors, and institutions, areas where this article expands ecodesign, using examples of large scaled environmental technology systems. Business models offer possibilities for operationalization, such an expanded view on product- 
service systems, due to their room for consideration of technological as well as nontechnological factors. 


\section{Method}

This section discusses the logic used to select the case companies, how data were collected, and how the data were used. As stated in the introduction, the goal of this article is thus twofold: to offer an expanded view on ecodesign of Product Service Systems (PSS) using a perspective of large technical systems, and to propose and discuss important components to consider when developing business concepts for the diffusion of large scaled environmental technology systems. Since business modelling based on large scaled environmental technology systems is a still a budding research topic (Rohrbeck et al., 2013), we chose an explorative-qualitative approach (see Yin, 2008). We intend to shed light on the phenomenon under investigation by collecting and analysing data from selected cases and discussing potential generalization implications.

In this study, the case companies selected for in-depth investigation are characterised by large scaled environmental technology systems that require multiple actors, technical components, and institutions to collaboratively act for a common purpose. Table 1 presents the interview coverage and some overview information on the selected case companies. As shown in Table 1 , examples of such large scaled environmental technology systems include waste management systems (sorting, collection, transportation, and end-treatment), biogas for transportation systems (biogas production, distribution, and use), and incineration with energy recovery (electricity and district heating supply). The selected companies are an outcome of our focus on large scaled environmental technology system developers who are actively engaged in diffusion activities. In addition, our ability to access empirical information through face-to-face interviews and company documentation/website reading restricted the scope of our selected companies to Sweden. These companies enrich the study because with their focus on different environmental technology offerings (electricity and district heating, biogas production and distribution, and material recycling), any common pattern that emerges is of particular interest in capturing the core experiences of a particular phenomenon under investigation (Olausson and Berggren, 2012) - in this case technology diffusion.

The empirical data collection followed an in-depth investigation of selected cases with a combination of different data collection approaches and data sources. The first step in the data collection was to review scientific literature around the concepts of environmental technology and its diffusion, ecodesign, product service systems design, and business models, an approach that provided a theoretical point of departure both for the research design and input for the analysis of the empirical data (as depicted in Figure 1). Semi-structured face-to-face interviews, which lasted between 60 and 120 minutes, were conducted with selected top management and/or other employees who were actively involved in the development of business models for diffusion activities. As can be seen in Table 1, the interviewees included chief executive officers who made strategic decisions with an overview of the entire organization, as well as employees who were actively involved with business modelling and diffusion activities. The interview questions addressed large scaled environmental technology diffusion, including their particular characteristics, their business models, as well as barriers and drivers for the diffusion of such technologies. The interview guide was sent to the interviewees while booking the interview appointment to give them ample time to gather 
relevant empirical information. Two researchers conducted the interviews to enhance the diversity and interactions during the discussions with the possibility for follow-up questions. The interviews were transcribed within 24 hours of each interview and sent back to the interviewees for further validation. This step was done to keep the content accurate from both the interviewer and interviewee perspectives. Secondary data from the company websites and annual reports were used to complement this primary data, particularly in validating the information obtained from the interviews and also triangulating the gathered empirical data. The data collection was done in the spring and summer of 2012.

Table 1: List of interviewees and overview of selected companies.

\begin{tabular}{|c|c|c|c|c|c|}
\hline & $\begin{array}{l}\text { Tekniska Verken } \\
\text { AB Linköping }\end{array}$ & Usitall AB & Svensk Biogas & $\begin{array}{l}\text { Swedish Biogas } \\
\text { International }\end{array}$ & VafabMiljö \\
\hline $\begin{array}{l}\text { Position of } \\
\text { interviewee(s) }\end{array}$ & $\begin{array}{l}\text { Chief Executive } \\
\text { Officer } \\
\text { Head of Business } \\
\text { Development } \\
\text { Marketing } \\
\text { Director }\end{array}$ & $\begin{array}{l}\text { Chief Executive } \\
\text { Officer }\end{array}$ & $\begin{array}{l}\text { Chief Executive } \\
\text { Officer } \\
\text { Biogas Research } \\
\text { and Development } \\
\text { Manager }\end{array}$ & $\begin{array}{l}\text { Project Manager } \\
\text { and Process } \\
\text { Engineer }\end{array}$ & $\begin{array}{l}\text { Development } \\
\text { Engineer }\end{array}$ \\
\hline Established & 1902 & 2008 & 1995 & 2006 & 1983 \\
\hline Ownership & $\begin{array}{l}\text { A municipality in } \\
\text { south-eastern } \\
\text { Sweden }\end{array}$ & $\begin{array}{l}\text { A municipality in } \\
\text { south-eastern } \\
\text { Sweden }\end{array}$ & $\begin{array}{l}\text { A municipality in } \\
\text { south-eastern } \\
\text { Sweden }\end{array}$ & Private & $\begin{array}{l}12 \text { municipalities } \\
\text { in central Sweden }\end{array}$ \\
\hline $\begin{array}{l}\text { Large scaled } \\
\text { environmental } \\
\text { technology } \\
\text { system }\end{array}$ & $\begin{array}{l}\text { Electricity and } \\
\text { district heating } \\
\text { supply systems } \\
\text { from solid waste } \\
\text { incineration }\end{array}$ & $\begin{array}{l}\text { Electricity and } \\
\text { district heating } \\
\text { supply systems } \\
\text { from solid waste } \\
\text { incineration }\end{array}$ & $\begin{array}{l}\text { Biogas } \\
\text { production } \\
\text { systems } \\
\text { (production, } \\
\text { distribution, end- } \\
\text { use) }\end{array}$ & $\begin{array}{l}\text { Biogas digesters } \\
\text { and production } \\
\text { processes }\end{array}$ & $\begin{array}{l}\text { Solid waste } \\
\text { recycling and } \\
\text { biogas } \\
\text { production } \\
\text { systems }\end{array}$ \\
\hline Economics (year) & 2013 & 2012 & 2013 & 2013 & 2013 \\
\hline Turnover & SEK 5001 million & SEK 736000 & SEK 148 million & SEK 183 million & SEK 420 million \\
\hline $\begin{array}{l}\text { Earnings before } \\
\text { tax }\end{array}$ & SEK 510 million & SEK -7.3 million & SEK 1.4 million & SEK -48 million & SEK -852000 \\
\hline $\begin{array}{l}\text { Number of } \\
\text { employees }\end{array}$ & 915 & 5 & 24 & 32 & 204 \\
\hline
\end{tabular}

Source: authors' own compilation from company websites and annual reports compiled at http://www.nordicnet.net/ (accessed 28 May 2015)

\section{$<<$ Position of Table 1 $>>$}

The empirical data from the cases above serve different purposes in this article. First, the empirical data have been used to describe how the selected case companies engage business approaches to diffuse large scaled environmental technology systems (Section 4). In addition, particular characteristics of large scaled environmental technology that influence their diffusion have been identified from the empirical data in Section 5.2, and these characteristics serve as input for the proposed components of the business concepts described in Section 5.3. In analysing the collected data, a thematic approach was chosen (Stebbins, 2001; Wolcott, 2008). In this approach, we iteratively looked for emerging themes and patterns in the collected data relevant for the goals of this paper. This iterative search for themes and patterns was done by the two researchers who participated in the interviews to guarantee content validity. Our proposed components of business concepts have also been presented to the studied companies for their feedback and corroboration. In addition to the corroboration with the studied companies, we also cross-checked our proposed components with aspects which 
the interviewees had explicitly ranked as important in the diffusion of large scale environmental technology systems. The method for the entire study is summarised in Figure 2 below.

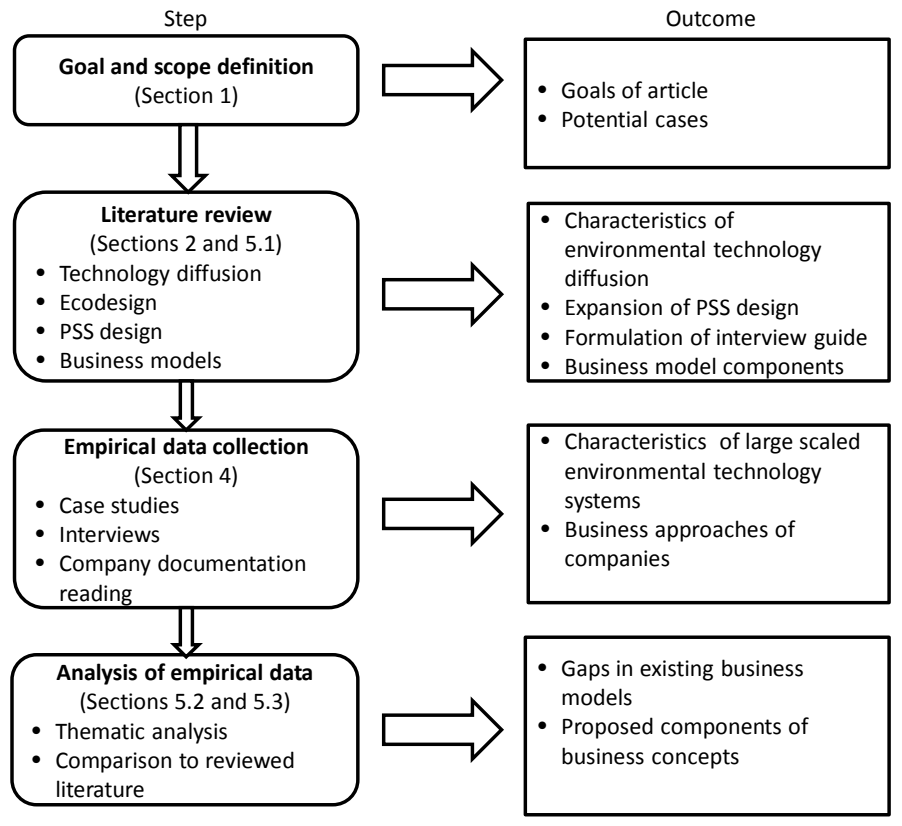

Figure 2: Summary of the method followed in entire study.

$<<$ Position of Figure 2>> 


\section{Empirical findings}

In this section we present empirical findings on the diffusion of large scaled environmental technology systems by selected companies. In total, four case companies (Usitall AB, Svensk Biogas, Swedish Biogas International and VafabMiljö) related to district heating supply, waste management, and renewable energy systems are presented based on interviews and documentation studies mentioned in Table 1 in the method section. The activities of Tekniska Verken AB Linköping are integrated into its subsidiary company, Usitall AB, which is mainly responsible for diffusion activities.

\subsection{Case 1: Usitall AB (waste-to-energy systems)}

Usitall AB, a subsidiary of Tekniska Verken AB Linköping, was established in 2008 to engage in the diffusion of waste-to-energy solutions based on the resources and competence of its parent company. Usitall AB specializes in the development of waste-to-energy projects (district heating and electricity supply from solid waste incineration). Its targeted markets are Central and Eastern European countries based on the (i) projected availability of raw materials (i.e., municipal solid waste), (ii) demand for heating and already existing district heating infrastructure, (iii) European Union legislation banning the landfilling of organic waste, and (iv) the non-existence of established strong competitors in the market. The company's business development consists of four phases: (i) establishment; (ii) secure sponsor; (iii) secure financing; and (iv) construction (Figure 3). Each stage has a particular activity, since this business development is based on their core competence, i.e. the ability to develop and operate waste-to-energy systems in collaboration with other competencies such as knowledge of local culture and legal requirements, which is often gathered with the help of other partners.

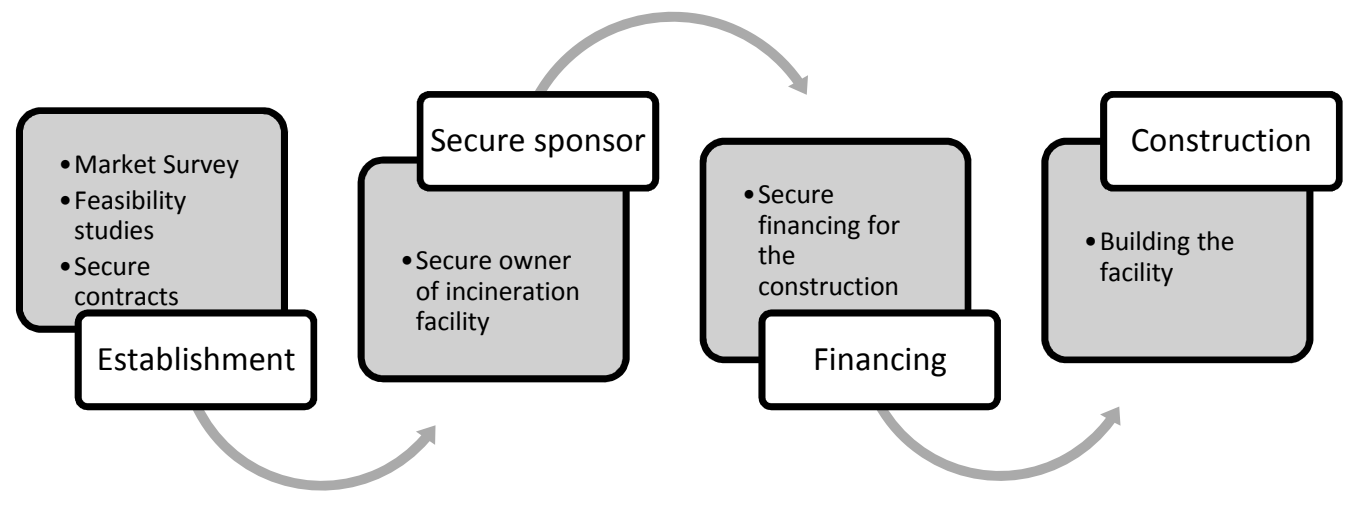

$<<$ Position of Figure 3>>

Figure 3. Phases in Usitall's business development.

The entire project of constructing a waste-to-energy facility for incineration with energy recovery is estimated to take between seven and ten years from securing the first agreement to finished construction. The characteristics of the raw material and the end-products being dealt with in these projects means that the business model has to accommodate different kinds of 
markets interacting with each other. These include the waste-as-material market that determines their access to waste as raw material, the technical market from which to choose appropriate technologies, and the commercial market for the heat and electricity produced. Dealing with these different but related markets can be a difficult and demanding task, as the company has to meet both formal and informal expectations from various actors and institutions in these different markets to conduct business successfully. Usitall AB has used incineration plants that have been built and run by its parent company, Tekniska Verken $\mathrm{AB}$ Linköping, for several years as a reference project to build trust, demonstrate competence and gain legitimacy from relevant actors and institutions in the diffusion of waste-to-energy system solutions.

\subsection{Case 2: Swedish Biogas International (Biogas digesters and production processes)}

Swedish Biogas International (SBI), established in 2006, specializes in building and operating biogas production facilities. The target customers are municipalities in Sweden and other countries such as the USA and South Korea. The company's operations in South Korea have been terminated partly because of differences between the home and the host market (e.g., differences in customer preferences, business culture, laws, and regulations). The company was engaged in these markets mainly because of the availability of secured public funding to undertake the biogas projects, supply of raw materials, and the demand for the end products from the biogas production. Future market interests include Poland and other Baltic countries because of the demand for proper end-treatment of farm residues and run-off threatening the Baltic Sea. SBI employs an active marketing strategy through participation in conferences, advertisement, exhibitions, and guided tours of its biogas production facilities to potential customers. SBI often employs a variety of approaches to enter a market depending on the target customer. SBI has entered new markets by focusing on government-funded projects (e.g., entering the US market was facilitated by a grant agreement between the Michigan economic development agency and the Swedish government) as well as by developing biogas plants for self-financed private customers (e.g., farmers with biogas production raw materials). SBI also offers services for optimization of the biogas production process at a fee. The company also builds industrial-sized plants for municipalities and other larger customers with business approaches customized to fit the various markets and customer needs. This focus on providing individualized services is due to the fact that each customer uses different input material, each country has its own regulations, and the products from the biogas production process have different market value based on customer preferences, market incentives, and regulations. For example, biogas as a vehicle fuel is not a very interesting option in the US because of the low prices for competing fossil-based vehicle fuels. In addition, in some states of the US, the raw materials for biogas production, for example from animal slaughter, are not sorted and thus contain a mixture of digestible and non-digestible components that have to be pre-sorted before use. The company thus has to be aware of the different regulations in different markets and how these regulations influence the design and operation of their biogas plants, including business models for their diffusion. 


\subsection{Case 3: VafabMiljö (waste-to-energy and material recycling systems)}

Vafab Miljö is a municipality-owned company focused on solid waste management with over 30 years of experience. The company specializes in anaerobic digestion of organic waste and solid waste material recycling collected from owner municipalities. The company interest in market expansion is partly motivated by the objective to recruit and keep employees by being an attractive place to work and to contribute to global sustainability. In their approach, the parent company dedicates some of its employees to finding financial aid from international development-oriented organizations such as the Swedish Agency for International Aid (SIDA) so they can engage in market expansion projects abroad. The company's foreign market expansion activities are thus pre-financed before the commencement of any such activity. VafabMiljö deals with large technical systems such as waste management systems focused on the recycling of solid waste. Such systems incorporate the collection, transportation, and end-treatment of waste, and the delivery of the end product to the market. To be able to develop such a proper functioning waste management system requires effective waste management regulatory frameworks, the cooperation of citizens through proper waste sorting, and the existence of companies to provide end-treatment including a viable market for end products. The company thus collaborates with other actors such as politicians, universities, private companies, and citizen groups (both home and abroad) to undertake such market expansion activities. To some extent, the content of their activities is determined by the funding agency that supports the project, a relationship that also contributes to their legitimacy based on the international reputation of such funding agencies.

\subsection{Case 4: Svensk Biogas (Biogas production systems)}

Svensk Biogas focuses on biogas production from organic waste, distribution and use as vehicle fuel. The company's research and development $(R \& D)$ unit focuses on developing knowledge and competence for optimizing biogas production processes; with expertise in this area, the R\&D unit occasionally undertakes diffusion initiatives outside its owner municipality both in Sweden and abroad. As the R\&D unit is in the very early phases of market expansion activities, it simultaneously uses different business approaches, including licensing patent agreements, securing government-funded projects, using city networks and responding to unsolicited customer requests. Their main source of market expansion activities has been through a licensing agreement with Kemira, a private chemical manufacturing company headquartered in Finland and operating throughout Europe, serving customers in waste-intensive industries. The R\&D unit has developed an additive for biogas optimization which is part of a product manufactured and sold by Kemira. Svensk Biogas then receives a license fee based on the amount of this product Kemira sells. In addition, the R\&D unit has had two small projects abroad in Malta and Estonia that aim to optimize biogas production processes in already-established biogas production facilities. These facilities pay Svensk Biogas for consulting hours and the delivery of technical reports. Svensk Biogas markets their offerings by attending industrial conferences and also participating in their owner city's networking abroad. The use of such city networks and industrial conferences is a way of getting access to foreign market information, getting international attention and also gaining some legitimacy from relevant stakeholders, since often large-scale biogas production systems are owned by cities which can relate more to the challenges and solutions of other cities. 
Future targets for market expansion include the United Kingdom and some countries in Eastern Europe partly motivated by a high concentration of biogas plants, which gives an indication of the potential need for technical competence on production processes and optimization.

\section{Components of business concepts: synthesis and discussion}

In this section we synthesise and discuss components of business concepts for the diffusion of large scaled environmental technology systems. We refer to our proposed components as part of a business "concept", since they represent a higher level of abstraction derived from our specific case studies compared to a business "model". We start with a review of some previous literature which covers business models on products, services and PSS in Section 5.1. In Section 5.2, we identify characteristics of large scaled environmental technology systems based on our case studies that were particularly influential in their diffusion. Finally, in Section 5.3 we propose components of business concepts for the diffusion of large scaled environmental technology systems based on gaps between basic components synthesized from the business model literature as well as particular characteristics identified from our case studies.

\subsection{Review of relevant business models}

As a definition, Amit and Zott (2001) state that "a business model depicts the content, structure, and governance of transactions designed so as to create value through the exploitation of business opportunities". Previous literature presents various perspectives on business models under the broad umbrella of sustainability. Boons and Lüdeke-Freund (2013) review literature on business models for sustainable innovation and propose four general normative requirements of business models for successful marketing of "sustainable innovations" as: value proposition, supply chain, customer interface and financial model. Building on the literature review by Boons and Lüdeke-Freund (2013), Bocken et al. (2014) provide a categorisation of sustainable business model archetypes based on a review of both academic literature and industry practices. They present three general groupings on the dominant areas of innovation under sustainable business models as: technological, social, and organisational-oriented innovations. The technological grouping includes archetypes with a dominant technical innovation component (e.g. manufacturing processes and product design); the social grouping covers social innovation components such as innovations in consumer offerings and changing consumer behaviour; and archetypes in the organizational grouping have a dominant organisational innovation change component.

This article mainly deals with technological innovations (district heating supply, waste management, and renewable energy systems), but the socio-technical nature of such systems in focus means that they have some social and organizational aspects as well (cf. Bocken et al., 2014). Below is a description of more concrete business models from selected literature that we deem relevant for the studied large technical systems. These selected business models follow the space of expansion from ecodesign from products and services to product-service systems. Osterwalder and Pigneur (2010) present a general business model that can be applied across different offerings, types, and industrial sectors. Mason and Spring (2011) present 
business models for products, whereas Lay et al. (2009) present business models based on products and services in business-to-business contexts. Okkonen and Suhonen (2010) discuss business models for heat energy production typical of large technical systems. These selected business models are elaborated on below.

As a practical guide, Osterwalder and Pigneur (2010) introduce the "business model canvas" that builds on nine blocks: key activities, key partnerships, key resources, cost structure, revenue streams, channels, value proposition, customer segments, and customer relationships. For physical products such as music players, Mason and Spring (2011) propose the "business model framework", which consists of three core elements for business modelling: technology, market offering, and network architecture. These core elements are based on theories in technology and innovation studies, industrial marketing, operations strategy, and evolutionary economics. Each element has multiple dimensions (Figure 4).

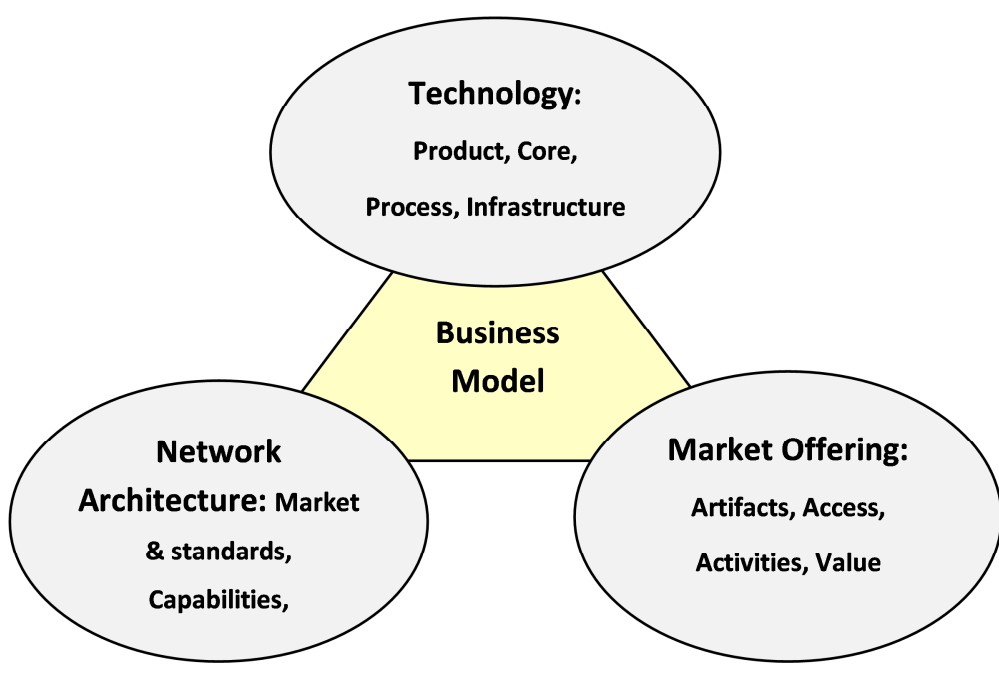

$<<$ Position of Figure 4>>

Figure 4. Business model framework (Mason and Spring 2011).

For combined product and service offerings, Lay et al. (2009) identify relevant parameters to describe business models: ownership during phase of use, ownership after phase of use, responsibility for production personnel, responsibility for maintenance personnel, payment model, number of customers, and location of operation. Each parameter has several options, as shown in Figure 5. 


\begin{tabular}{|c|c|c|c|c|c|c|c|}
\hline \multicolumn{2}{|c|}{ Characteristic Features } & \multicolumn{6}{|c|}{ Options } \\
\hline \multirow[b]{2}{*}{ Ownership } & $\begin{array}{c}\text { During } \\
\text { phase of use }\end{array}$ & $\begin{array}{l}\text { Equipment } \\
\text { producer }\end{array}$ & \multicolumn{2}{|c|}{ Leasing bank } & \multicolumn{2}{|c|}{$\begin{array}{l}\text { Operating joint } \\
\text { venture }\end{array}$} & Customer \\
\hline & $\begin{array}{l}\text { After phase } \\
\text { of use }\end{array}$ & $\begin{array}{l}\text { Equipment } \\
\text { producer }\end{array}$ & \multicolumn{2}{|c|}{ Leasing bank } & \multicolumn{2}{|c|}{$\begin{array}{l}\text { Operating joint } \\
\text { venture }\end{array}$} & Customer \\
\hline \multirow[t]{2}{*}{ Personnel } & Manufacturing & \multicolumn{2}{|c|}{ Equipment producer } & \multicolumn{2}{|c|}{$\begin{array}{l}\text { Operating joint } \\
\text { venture }\end{array}$} & \multicolumn{2}{|c|}{ Customer } \\
\hline & Maintenance & \multicolumn{2}{|c|}{ Equipment producer } & \multicolumn{2}{|c|}{$\begin{array}{l}\text { Operating joint } \\
\text { venture }\end{array}$} & \multicolumn{2}{|c|}{ Customer } \\
\hline \multicolumn{2}{|c|}{ Location of operation } & \multicolumn{2}{|c|}{$\begin{array}{l}\text { Equipment producer's } \\
\text { establishment }\end{array}$} & \multicolumn{2}{|c|}{$\begin{array}{l}\text { Establishment "fence to } \\
\text { fence" to the customer }\end{array}$} & \multicolumn{2}{|c|}{$\begin{array}{c}\text { Customer's } \\
\text { Establishment }\end{array}$} \\
\hline \multicolumn{2}{|c|}{$\begin{array}{l}\text { Single/multiple customer } \\
\text { operation }\end{array}$} & \multicolumn{3}{|c|}{$\begin{array}{l}\text { In parallel operation for multiple } \\
\text { customers }\end{array}$} & \multicolumn{3}{|c|}{ Operation for a single customer } \\
\hline \multicolumn{2}{|c|}{ Payment model } & Pay per unit & \multicolumn{2}{|c|}{$\begin{array}{c}\text { Pay for } \\
\text { availabilitv }\end{array}$} & \multicolumn{2}{|c|}{ Fixed rate } & $\begin{array}{l}\text { Pay for } \\
\text { equipment }\end{array}$ \\
\hline
\end{tabular}

Figure 5. Morphological Box as a framework to describe new business concepts (Lay, et al. 2009).

Looking at the area of heat energy production, Okkonen and Suhonen (2010) researched several factors influencing transfer of know-how and technologies between regions, transferred objects, stakeholders involved in processes, and transfer media. They propose four main parameters in business models: investment, ownership, operation (e.g., heat production and fuel supply), and earning logic.

From the reviewed literature of business models, we synthesized six components as a foundation for our business concept components. The synthesis steps are elaborated on in Section 5.3 where they directly connect to components of the business concept for the diffusion of large scaled environmental technology systems. From the literature, our synthesized basic components are:

- Market

- Finance

- Resources

- Activities

- Partnership

- Ownership and responsibility

Market refers to a system through which producers and customers engage in exchanges. Finance covers both the cost incurred in creating customer value and the revenue obtained from delivering customer value, as well as its appropriation among actors involved in the business concept. Finance encompasses key revenue streams, payment model, and cost structure. Key resources refer to the technological, financial, and intellectual competence 
needed to exploit a business opportunity and to create customer value. These key resources are needed to create and deliver the customer value. Activities refer to vital activities that the firm undertakes to exploit business opportunities. Partnership refers to key partners needed for the business concept to function. Ownership and responsibility covers the assignment of ownership and responsibility for the technology during use and after use if applicable.

The components synthesised above from previous literature form a basis to develop business concepts for the diffusion of large scaled environmental technology systems. These basic components synthesised from the literature are further enriched with specific characteristics of large scaled environmental technology systems identified in our analysis in the next section.

\subsection{Analysis of characteristics of large scaled environmental technology systems}

To develop business concepts for large scaled environmental technology systems, it is necessary to identify their particular characteristics. Table 2 summarizes such characteristics on the left based on the empirical cases presented in Section 4. On the right, Table 2 shows each characteristic's reference or relation to existing scientific literature. For instance, González (2009) identified several characteristics of environmental technologies that may affect their development and diffusion:

- "the inertia to stick to existing technologies";

- complexity (e.g., additional training is needed);

- compatibility with the existing production systems; and

- high initial investment.

In addition, for the development and diffusion of different types of environmental technologies, different determinants should be considered depending on the country (González, 2009). For instance, adoption and use of most end-of-pipe technologies such as air pollution filters and wastewater treatment is typically influenced by regulation, since many firms have traditionally perceived investment in such technologies as an extra cost as they are often add-ons to existing production systems for environmental protection and clean-up (González, 2009). In addition, Corvellec and Bramryd (2012) studied the business model of two waste management companies in Sweden and found that these companies deal with four different markets: political, waste-as-material, technical, and commercial. Working with all of these markets, which have different attributes and interrelationships, are strategic challenges for such companies (Corvellec and Bramryd, 2012). 
Table 2. Characteristics of large scaled environmental technology systems.

\begin{tabular}{|l|l|}
\hline $\begin{array}{l}\text { From the interviews } \\
\text { Complexity with several technical } \\
\text { components, actors and institutions } \\
\text { (interviews, Usitall AB; SBI; VafabMiljö) }\end{array}$ & $\begin{array}{l}\text { Complexity exhibited by some environmental } \\
\text { technology types requires additional training } \\
\text { for the workforce upon adoption (González } \\
\text { 2009) }\end{array}$ \\
\hline $\begin{array}{l}\text { Importance of financing (interviews, SBI; } \\
\text { Usitall AB; Svensk Biogas) }\end{array}$ & High initial investment (González 2009) \\
\hline $\begin{array}{l}\text { Need to address different market types } \\
\text { (interviews, Usitall AB; SBI) }\end{array}$ & $\begin{array}{l}\text { Environmental technology companies have to } \\
\text { compete and remain legitimate in different } \\
\text { kinds of markets (Corvellec and Bramryd, } \\
\text { 2012) }\end{array}$ \\
\hline $\begin{array}{l}\text { Need to adapt to the target market } \\
\text { (including regulation) (interviews, SBI; } \\
\text { Usitall AB) }\end{array}$ & $\begin{array}{l}\text { Compatibility with the existing production } \\
\text { system (Mejía-Dugand et al., 2012) }\end{array}$ \\
\hline $\begin{array}{l}\text { Relevance of systems approach (including } \\
\text { social and human aspects) (interviews, } \\
\text { VafabMiljö; Usitall AB) }\end{array}$ & $\begin{array}{l}\text { Sustainability-driven innovations require } \\
\text { multiple organizations to act in an an } \\
\text { orchestrated fashion (Rohrbeck et al., 2013) }\end{array}$ \\
\hline
\end{tabular}

$<<$ Position of Table 2>>

Now, the ultimate question is "how can one support the design of this type of business concept?" In seeking an answer to this, the authors have selected characteristics of the business concept to be developed. The business concept should address a systems approach including non-technological dimensions, the complexity of large scaled environmental technology systems and the influence of market regulations in their diffusion, as pointed out in the case descriptions in Table 2 above.

\subsection{Adjustment of existing business model components}

To formulate business concepts based on environmental technology offerings we used an iterative three-step process to synthesize components from existing business model literature (Section 5.1), to extract relevant characteristics of large environmental technology systems from empirics (Section 5.2), and to formulate business concepts for their diffusion (Section 5.3). Figure 6 below depicts our approach. 


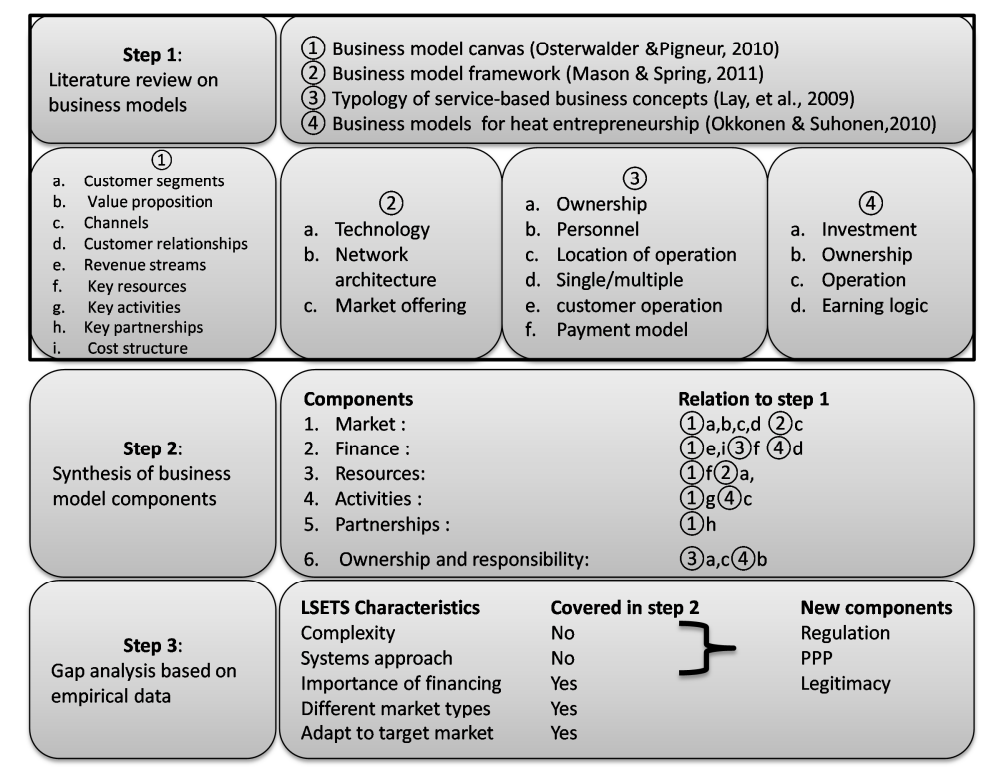

\section{$<<$ Position of Figure 6>>}

Figure 6. Adjustment of existing business model components to large scaled environmental technology systems. LSETS in the figure refers to large scaled environmental technology systems.

Based on the analysis of previous literature and empirical analysis, the article proposes adjustment of the important components for a business concept synthesised from the existing literature. First, we add legitimacy as a new component. Second, we add two sub-components: regulation under market and public-private partnership under partnership. See the sub-section below for a deeper discussion on the new (sub) components and the reasoning behind their addition, and more importantly their relation to our case studies. Altogether, there are seven components and two sub-components of the proposed business concept for the diffusion of large scaled environmental technology systems:

- Market

○ Regulation

- Finance

- Resources

- Activities

- Partnership

- Public-private partnership

- Ownership and responsibility

- Legitimacy

In developing the above set of components, Step 1 as shown in Figure 6 followed a review of academic literature to establish a basic foundation on business models. This step was based on 
the understanding that there were a number of existing approaches for business modelling in general, and that business modelling for large scaled environmental technologies would share certain similarities with existing approaches. Both generic business models (Mason and Spring, 2011; Osterwalder and Pigneur, 2010) and specific business models - i.e., models that deal with product service offerings (Lay et al., 2009) and entrepreneurship - address heat entrepreneurship (Okkonen and Suhonen, 2010) were reviewed. The focus was on reviewing different approaches to business modelling - a selection strategy for complementary outcomes (Yin, 2008). As stated earlier, the four business models we selected also follow the space into which this article expands ecodesign for products, service systems, and to large technical systems.

In Step 2, the notion of a similarity and complementarity outcome among different sources about a particular phenomenon was used in synthesising and abstracting from previous literature. As explained by Olausson and Berggren (2012), any common pattern that emerges from variation of sources is of particular interest when analysing the shared dimensions of a particular phenomenon. In total, six components were synthesized at the end of this step. The relation of the synthesised components to the existing components of business models is shown in Step 2, Figure 6.

In Step 3, we compared the characteristics of large scaled environmental technology systems found from the empirical data with the synthesized components from the business model literature. As can be seen in Figure 6, some of the characteristics of large scaled environmental technology systems (LSETS) are covered by existing business modelling approaches, although their "complexity" and "systems approach" are not explicitly addressed. We introduce one new component, Legitimacy, and two new sub-components, Regulation as part of "Market" and public-private partnership (PPP) as part of "Partnerships", to explicitly address and lay emphasis on their systemic nature and complexity. Even though these new (sub) components are linked to the "complexity" and "systems approach" of large environmental technology systems, they also interact with their other characteristics, such as their relatively high financial investments compared to products and services, and also the need to adapt to different market conditions. These new components are influenced by the characteristics of our selected cases, but similarities can be drawn to other large technical systems such as telecommunication and railway systems (Markard and Truffer, 2006). The new components, which are particular for the diffusion of large environmental technology systems, are discussed further below.

The addition of private-public partnership is motivated by the systemic nature of such large scaled environmental technology systems, as different actors have to collaborate (Rohrbeck et al., 2013) to enable the proper functioning of the system. For example, public funders and private companies need to collaborate to finance such large scaled environmental technology systems because of the high capital investments and the risks involved. For instance, as the case studies indicate, the entry of Swedish Biogas International into the US market was facilitated by a grant agreement between the Michigan economic development agency and the Swedish government (interview, Swedish Biogas International Project manager and process engineer). Similar emphasis on private-public partnership is mentioned by the Chief 
Executive Officer of Usitall as important in securing financing for the establishment of wasteto-energy facilities because of the relatively high investment and risks involved (interview, Usitall Chief executive officer). As indicated in the case of VafabMiljö, collaboration between public and private actors goes beyond financing to construction, ownership and operation of systems for waste collection and recycling facilities. To develop a functioning waste management system requires effective waste management regulatory frameworks, the cooperation of citizens through waste sorting, and the existence of companies to provide endtreatment for waste fractions (interview, VafabMiljö Development engineer).

The sub-component regulation is emphasised as a new sub-component because of the significant influence regulations have on the diffusion of environmental technology (del Rio González, 2009). Regulations define what is meant by waste, its characteristics and what the outcomes of its processing should be in different markets. As indicated by Usitall, waste-toenergy systems interact with different markets which are highly regulated. For example, dealing with waste as a raw material, technological choices for waste treatment and the commercial market for electricity and heat are issues of strategic management, particularly in international diffusion activities (interview, Usitall Chief executive officer). Relating to the literature, Corvellec and Bramryd (2012) recognise that companies dealing with waste-toenergy systems tackle different kinds of markets, and need to follow the regulations for these markets to operate, and more so to meet stipulated standards such the environmental targets as well as gain legitimacy. This is particularly the case for Swedish Biogas International (SBI), who modifies their technologies and services based on the raw material and regulations on the target market. For example, biogas as a vehicle fuel is not a very attractive option for SBI in the US because of the low prices for competing fossil-based vehicle fuels. In addition, regulations in some parts of the US mean the raw materials for biogas production from animal slaughter are not sorted and often contain indigestible components that have to be pre-sorted before processing (interview, Swedish Biogas International Project manager and process engineer).

Legitimacy, as a new component, refers to social acceptance and the compliance with relevant institutions and regulations (Bergek et al., 2008). The technology provider needs to be considered capable and trustworthy by relevant actors for resources to be made available, for demand to form and to collate the systemic actors needed around such large technical systems. For example, to develop waste management systems abroad, VafabMiljö requires the cooperation of citizens through proper waste sorting, collaboration with potential partners for ownership, management, and proper end-treatment of sorted waste. The company thus collaborates with other actors such as policy makers, educators, private companies, and citizen groups and must gain the trust of such actors for activities to progress (interview, VafabMiljö Development engineer). Gaining the trust of such stakeholders would be influenced to some extent by the legitimacy of the technology and its provider and its alignment with existing formal and informal expectations. The process of legitimation is not given, is complicated, and takes a long time (Bergek et al., 2008). Strategies for legitimation also include "manipulation" (i.e., changing the rules of the game), "conformance" (i.e., choosing to follow existing social and formal expectations), and "creation" (i.e., influencing 
and developing new institutional frameworks). In the case of environmental technologies, achieving legitimacy through compliance can follow conscious company strategies to comply with market regulations and standards, proof of concept and long-term operations, and sustainability meanings of the business concept to enable the provider to build competence and trustworthiness. Analysing the legitimacy of the technology and its providers from the perspective of relevant actors could prove important in the diffusion of large scaled environmental technology systems.

The proposed components of business concepts can serve as important discussion points for practitioners when planning the diffusion of large scaled environmental technology systems. Several systematic plans of action can be taken by the technology provider based on their position in relation to the proposed components. For example, the proposed new components of business concepts could be incorporated into existing business models used by technology providers such as the business model canvas.

Relating to reviewed literature on the diffusion of environmental technology in general, Beise and Rennings (2005) contribute with factors influencing the diffusion of environmental technologies on the national level, Fichter and Clausen (2012) focus on relevant factors from the perspective of the environmental technology provider, and del Río González (2005) provide insight from the environmental technology adopter's perspective. Hockerts and Wüstenhagen (2010) provide understanding on the roles of different types of environmental technology providers, while Carrillo-Hermosilla et al. (2010) identify key dimensions of environmental technologies that influence their environmental performance and market introduction. On the other hand, (Bocken et al., 2014); Boons and Lüdeke-Freund (2013); (Boons et al., 2013) discuss aspects of business models for sustainable innovation which are coherent with the new components identified in this paper particularly relating to legitimacy, regulation and private public partnership. In relation to these previous contributions, this article extends the discourse on how technology providers can deal with the business aspects of diffusion, a discussion which is still budding in the literature.

\section{Conclusions and further research}

This article started with two goals: to offer an expanded view on ecodesign of PSS using a perspective of large technical systems, and to propose and discuss important components to consider when developing business concepts for the diffusion of large scaled environmental technology systems. Specifically, this article represents a first attempt to expand ecodesign of products and PSS to that of large technical systems by considering the potential system-wide environmental benefits, a discussion that has been missing in previous literature on PSS and sustainability, even though many researchers have suggested this as a necessary step. We argue that the focus on large technical systems can be facilitated by business concepts that include technological and non-technological aspects, and thus potentially offering the opportunity for even more system-wide environmental improvements through changes in norms, user behaviours, and regulations, than for example technological changes in products and services alone. In addition, we provide components for such business concepts based on 
large scaled environmental technology systems that practitioners could use to focus their discussions on when planning the diffusion of such environmental technology with particular attention to regulation, public-private partnership, and legitimacy based on the characteristics of large scaled environmental technology systems. For practitioners engaged in the development and diffusion of such large technical systems, a consideration of the proposed business concept components could support their activities and potentially contribute to their success.

For further research, the discussions from the theoretical expansion of ecodesign of PSS and the proposed components of business concepts for large scale environmental technology systems opens up interesting discussions, particularly relating to the environmental benefits of such expansion, the relation between the proposed components, and the operationalization of the business concept component. Researchers could analyse more cases to exploit the proposed business concept components in the diffusion of environmental technologies. An interesting follow-up to this study might include analysing how to operationalize the components of the business concept in practise. For example, a small-sized company interested in the diffusion of its environmental technology might have to partner with a larger company to develop proof of concept and demonstrate long-term operations in certain markets as a way of building legitimacy. In addition, since regulations in many markets stipulate the environmental performance of technologies (e.g., emissions from biogas production and incineration plants), a company considering such factors in their diffusion approach is likely to incorporate such regulation targets and develop better environmentally performing systems while building legitimacy among several actors, users, and institutions connected with the large technical system.

\section{Acknowledgement}

We are grateful to Tekniska Verken's Industrial Ecology Research Programme for their financial support to undertake this study as part the BMEX project (Business Models for Market Expansion of Swedish Municipal Companies). We also want to express our sincere gratitude to the interviewees for making time to participate in the interviews. Special thanks also go to Sahar Sadri of Linköping University for taking part in conducting the interviews.

\section{References}

Alting, L., Legarth, J.B., 1995. Life Cycle Engineering and Design. Annals of CIRP 44, 569-580.

Baumann, H., Boons, F., Bragd, A., 2002. Mapping the green product development field: engineering, policy and business perspectives. Journal of Cleaner Production 10, 409-425.

Beise, M., Rennings, K., 2005. Lead markets and regulation: a framework for analyzing the international diffusion of environmental innovations. Ecological Economics 52, 5-17.

Bergek, A., Jacobsson, S., Carlsson, B., Lindmark, S., Rickne, A., 2008. Analyzing the functional dynamics of technological innovation systems: A scheme of analysis. Research policy 37, 407429.

Bocken, N., Short, S., Rana, P., Evans, S., 2014. A literature and practice review to develop sustainable business model archetypes. Journal of Cleaner Production 65, 42-56. 
Boehm, M., Thomas, O., 2013. Looking beyond the rim of one's teacup: a multidisciplinary literature review of Product-Service Systems in Information Systems, Business Management, and Engineering \& Design. Journal of Cleaner Production 51, 245-260.

Boons, F., Lüdeke-Freund, F., 2013. Business models for sustainable innovation: state-of-the-art and steps towards a research agenda. Journal of Cleaner Production 45, 9-19.

Boons, F., Montalvo, C., Quist, J., Wagner, M., 2013. Sustainable innovation, business models and economic performance: an overview. Journal of Cleaner Production 45, 1-8.

Carrillo-Hermosilla, J., Del Río, P., Könnölä, T., 2010. Diversity of eco-innovations: Reflections from selected case studies. Journal of Cleaner Production 18, 1073-1083.

Cerin, P., Axelsson, U., Ekengren, Ö., 2007. Research, Development and Demonstration Strategies on Environmental Technology - Suggested foundations for a Formas-Vinnova strategy.

Corvellec, H., Bramryd, T., 2012. The multiple market-exposure of waste management companies: A case study of two Swedish municipally owned companies. Waste management 32, 17221727.

del Rio González, P., 2009. The empirical analysis of the determinants of technologicall change: A research agenda. Journal of ecological economics, 861-878.

del Río González, P., 2005. Analysing the factors influencing clean technology adoption: a study of the Spanish pulp and paper industry. Business strategy and the environment 14, 20-37.

Dirgahayani, P., 2013. Environmental co-benefits of public transportation improvement initiative: the case of Trans-Jogja bus system in Yogyakarta, Indonesia. Journal of Cleaner Production 58, 74-81.

Fichter, K., Clausen, J., 2012. Diffusion paths of sustainability innovations. Borderstep, Berlin, p. 6. Fiksel, J., 1996. Design for Environment. Mc Graw Hill, New York.

Guziana, B., 2011. Is the Swedish environmental technology sector 'green'? Journal of Cleaner Production 19, 827-835.

Hockerts, K., Wüstenhagen, R., 2010. Greening Goliaths versus emerging Davids-Theorizing about the role of incumbents and new entrants in sustainable entrepreneurship. Journal of Business Venturing 25, 481-492.

Kanda, W., Mejía-Dugand, S., Hjelm, O., 2013. Governmental export promotion initiatives: awareness, participation, and perceived effectiveness among Swedish environmental technology firms. Journal of Cleaner Production.

Karlsson, R., Luttropp, C., 2006. EcoDesign: what's happening? An overview of the subject area of EcoDesign and of the papers in this special issue. Journal of Cleaner Production 14, 12911298.

Kemp, R., Volpi, M., 2008. The diffusion of clean technologies: a review with suggestions for future diffusion analysis. Journal of Cleaner Production 16, S14-S21.

Knight, P., Jenkins, J.O., 2009. Adopting and applying eco-design techniques: a practitioners perspective. Journal of Cleaner Production 17, 549-558.

Lay, G., Schroeter, M., Biege, S., 2009. Service-based business concepts: A typology for business-tobusiness markets. European Management Journal 27, 442-455.

Lindahl, M., 2005. Engineering designers' requirements on design for environment methods and tools. KTH.

Lindahl, M., Sundin, E., Sakao, T., 2014. Environmental and Economic Benefits of Integrated Product Service Offerings Quantified with Real Business Cases. Journal of Cleaner Production 64, 288296.

Markard, J., Truffer, B., 2006. Innovation processes in large technical systems: Market liberalization as a driver for radical change? Research policy 35, 609-625.

Mason, K., Spring, M., 2011. The sites and practices of business models. Industrial Marketing Management 40, 1032-1041.

Meier, H., Roy, R., Seliger, G., 2010. Industrial Product-Service Systems - IPS². CIRP Annals Manufacturing Technology 59, 607-627. 
Mejía-Dugand, S., Hjelm, O., Baas, L., Ríos, R.A., 2012. Lessons from the Spread of Bus Rapid Transit in Latin America. Journal of Cleaner Production.

Mont, O., 2002. Clarifying the concept of product-service system. Journal of Cleaner Production 10, 237-245.

Mont, O., Tukker, A., 2006. Product-Service Systems: reviewing achievements and refining the research agenda. Journal of Cleaner Production 14, 1451-1454

Montalvo, C., 2008. General wisdom concerning the factors affecting the adoption of cleaner technologies: a survey 1990-2007. Journal of Cleaner Production 16, S7-S13.

OECD, 2009. Eco-Innovation in Industry:Enabling green growth. OECD publishing, France.

Okkonen, L., Suhonen, N., 2010. Business models of heat entrepreneurship in Finland. Energy Policy 38, 3443-3452.

Olausson, D., Berggren, C., 2012. Managing asymmetries in information flows and interaction between $R \& D$, manufacturing, and service in complex product development. R\&D Management 42, 342-357.

Osterwalder, A., Pigneur, Y., 2010. Business model generation: a handbook for visionaries, game changers, and challengers. John Wiley \& Sons.

Ramani, K., Ramanujan, D., Bernstein, W.Z., Zhao, F., Sutherland, J., Handwerker, C., Choi, J.-K., Kim, H., Thurston, D., 2010. Integrated Sustainable Life Cycle Design: A Review. Journal of Mechanical Design 1332, 0910041-09100415.

Rennings, K., 2000. Redefining innovation-eco-innovation research and the contribution from ecological economics. Ecological Economics 32, 319-332.

Rennings, K., 2014. Introduction: Global diffusion of environmental innovations. Environmental Innovation and Societal Transitions 10, 1-3.

Rogers, E.M., 2010. Diffusion of innovations. Simon and Schuster.

Rohrbeck, R., Konnertz, L., Knab, S., 2013. Collaborative business modelling for systemic and sustainability innovations. International Journal of Technology Management 63, 4-23.

Sakao, T., Shimomura, Y., 2007. Service Engineering: a novel engineering discipline for producers to increase value combining service and product. Journal of Cleaner Production 15, 590-604.

Smith, D.J., 2013. Power-by-the-hour: the role of technology in reshaping business strategy at RollsRoyce. Technology Analysis \& Strategic Management 25, 987-1007.

Stebbins, R.A., 2001. Exploratory research in the social sciences. Sage.

Suzuki, M., 2014. Identifying roles of international institutions in clean energy technology innovation and diffusion in the developing countries: matching barriers with roles of the institutions. Journal of Cleaner Production.

Tukker, A., 2013. Product services for a resource-efficient and circular economy-a review. Journal of Cleaner Production.

Wang, C., Nordgren, S., Lindblom, B., Savonen, S., Hedpalm, T., Larsson, M., Hansson, R., 2010. Conceptual design of an integrated heating system at LKAB Malmberget with consideration of social-environmental damage costs. Journal of Cleaner Production 18, 944-951.

Wolcott, H.F., 2008. Writing up qualitative research. Sage Publications.

Yin, R.K., 2008. Case study research: Design and methods. SAGE Publications, Incorporated. 